\title{
Prevalence of Internet Addiction among Nursing Students and the Association with their Academic Performance and Mental Health
}

\author{
By Amal Ibrahim Khalil \\ Najla Burayk Alharbi ${ }^{\dagger}$ \\ Hadeel Yousef Alhawasawi ${ }^{+t}$ \\ Amani Baker Albander ${ }^{+}$
}

The objective was to investigate the prevalence of Internet Addiction (IA) among nursing students and its association with their mental health and academic performance, at king Saud Bin Abdul-Aziz. University for Health Sciences, Jeddah. A descriptive correlation exploratory design was used with 147 females students selected conveniently. A self-administered Arabic version of Young (1995) IA scale and depression scale developed by Radloff (1977) were used to collect data. Almost 2 thirds of the participants (59.6\%) were average on-line users compared with $38.4 \%$ and $2.1 \%$ experiencing both moderate, and sever IA, respectively. More than 2 thirds (64.6\%) were experienced with depressive symptoms compared with only $35.4 \%$, who were normal. A significant correlation was found between IA, time spent on the Internet, and depressive symptoms $(r=0.335$ and $r=0.205)$, respectively. Therefore, conducting an in-service training program of Internet use and promoting a supportive environment of counseling will decrease the psychological morbidity of stress and depression among college students.

\section{Introduction}

Losing control on using the Internet leads to uncontrolled behavior, that leads to difficulties in the users daily lives and their relationship (Ko et al. 2012, Young and Rogers 1998) describe as Internet addiction (IA) (Shapira et al. 2003, Holden 2001). More specifically, IA has been defined as excessive preoccupation with the Internet, recurring thoughts about limiting and controlling use of the Internet, inability to eliminate cravings for Internet access, continued use of the Internet despite impaired functioning in various domains, spending increasingly more time on the Internet, and experiencing longings and cravings for the Internet even when it is unavailable (Young and Rogers 1998, Pirzadeh 2012).

\footnotetext{
* Assistant Professor of Psychiatric and Mental Health, Nursing Menoufyia University, Egypt \& King Saud Bin Abdul-Aziz University for Health Sciences, College of Nursing, Jeddah, Saudi Arabia.

${ }^{\dagger}$ Undergraduate Nursing Student, King Saud Bin Abdul-Aziz University for Health Sciences, College of Nursing, Jeddah, Saudi Arabia.

* Undergraduate Nursing Student, King Saud Bin Abdul-Aziz University for Health Sciences, College of Nursing, Jeddah, Saudi Arabia.

${ }^{+}$Undergraduate Nursing Student, King Saud Bin Abdul-Aziz University for Health Sciences, College of Nursing, Jeddah, Saudi Arabia.
} 
Several studies have examined the prevalence of IA during the past few years. For example, a study conducted in the USA reported a prevalence of $1.0 \%$ (Ko et al. 2007). A study conducted in Europe reported a prevalence of 9.0\% (Christakis et al. 2011), and studies conducted in Asia reported prevalence ranging from $2.0 \%$ to $18.0 \%$ (Jenaro et al. 2007). However, data from those studies reported an inconsistent occurrence rate of IA, it is no doubt that IA has become a serious public health problem around the world (Jung Koo and Hye Kwon 2014), especially in adolescents (Sung et al. 2013). Previous studies suggested that IA increased the risk of suffering from a number of negative social and health consequences, such as poor academic performance, poor personality relationship, anxiety, depression (Jie et al. 2014) and other behavioral problems (Li et al. 2010, Lin et al. 2015).

The Internet has enlightened the community world by providing copious applications and well known benefits. These benefits have been widely investigated and comprise keeping in touch with colleagues, family partners through electronic email post, finding information about food, goods, and merchandize services. In addition to the services if transferring money, searching for jobs, and getting the recent and updating news of medical health information. Moreover, other Internet advantages include; downloading of recreational soft music, visiting discussion forums, engaging with entertainment games and assisting with educational and academic needs (Akhter 2013). However, the overuse and the absence of controlling behavior over its use might have created its own problems and the Internet addiction is the commonest one among Internet users (Kapahi et al. 2013, Jahanian and Seifury 2013, Zhang et al. 2015).

The risks to people and to the community include "decrease of communal, socialization and cognitive or constructive skills". Besides, other skills could be affected by Internet overuse such as loss of inspiration for more productive accomplishments, unemployment and daily living activities (Neumann 1998).

Many research studies indicate that, IA disrupts family functioning by leading to problems in users' daily lives and relationships among family members (Young and Rogers 1998, Ko et al. 2007, Christakis et al. 2011). Like other non-chemical addictions such as those involving gambling, sex, and shopping, the primary features of Internet addiction include preoccupation, emotional liability, tolerance, withdrawal, interpersonal conflict, and engagement in repetitive behaviors (Jenaro et al. 2007, Mohammadsalehi et al. 2015).

Nowadays, Internet is becoming an integral part of the daily life for many people in Saudi Arabia and it is spreading quickly. On the other hand, a considerable effort has been completed from the Saudi government and the Ministry of Communications to block sites that swarm offensive content and services for example undesired adult content, electronic games that contain gambling activities, and socializing and mixing relationship especially between two genders. These sites are prohibited as they conflict with the religious, cultural, legal and traditional norms. In fact, adolescents and university students are an at-risk group of population for Internet addiction because of 
their academic and educational needs or stressors that make them unable to control the time spent on line (Shaw and Black 2007). Alike, Internet addiction has been reported among $1.4 \%$ to $17.9 \%$ of young adult and university students in both Western and Eastern societies (Fu et al. 2010, Shaw and Black 2007).

College students experienced a lot of stressors throughout their life (Hosseini et al. 2015). Among those stressors that may involve different types of life events such as interpersonal problems, school related problems, family related problems and personal problems that are characterized by either a higher or lower frequency of occurrence. Accordingly, Jie et al. (2014) found in his study that life-stress from inter personal and school correlated positively with IA. Furthermore, Jie et al. (2014), Velezmoro et al. (2010), Li et al. (2010) concluded that life events that occur in higher frequency rather than life events that occur in lower frequency are induced to IA. In addition, Yan et al. (2013) in their study reported that, the interaction of traumatic life events and psychosomatic indications may increase the risk of IA. The relation between Internet addiction and mental health problems was reported in earlier studies. Nevertheless, depression is the most common mental disorder to be associated with Internet addiction among teenagers and university students (Yen et al. 2008). As well, several studies have been found as a relationship between insecure attachment styles and alcohol or drug addiction (McNally et al. 2003, De Rick and Vanheule 2007). Furthermore, a recent study about the relationship between Internet addiction and attachment styles (Shin et al. 2011) found an association between anxious and avoid ant styles and Internet addiction. In addition Jie et al. (2014) reported that the Internet addicts scored higher on the stressful life events, depression symptom and anxiety symptoms than the non-addicts, as the significances were only found on interpersonal problems, and school related problems and anxiety symptoms.

\section{Significance of the Study}

As, it has been reported that the estimated number of Internet users around the world reached 1,733,993,741 users by the end of September 2009 (Miniwatts Marketing Group 2010) which means that the Internet service has already penetrated to more than $25 \%$ of the world's population. This reflects a worldwide Internet user growth of more than $38 \%$ since the year 2000 . The topic of online addiction has fuelled a growing concern of the impact of virtual lives that people live online, on their real-world existence, or real-life with different factors related stressors. However, it remains unknown, whether Internet addiction is the cause or the consequence of depression, because most of these studies are cross-sectional by nature. As well, there is no evidence based research found whether there is or not an association between IA, academic performance and psychological morbidity for depression. Therefore, in the present study we were looking at identifying the prevalence of IA and its association with academic performance and mental health of nursing students at the nursing college affiliated to king Saud Bin Abdul-Aziz University for Health Sciences, Jeddah. 
The aim of the present study was to investigate the prevalence of IA and its association with academic performance and the mental health of nursing students studying at the Nursing college of king Saud Bin Abdul-Aziz University for Health Sciences, Jeddah. More specifically we looked at assessing the prevalence level of IA and depressive symptoms among the nursing students, examining the association between IA, academic performance and students' mental health, and exploring the correlation between academic performance, IA and participants' demographic characteristics.

\section{Methods}

\section{Participants and Methods}

$\underline{\text { Design }}$

An exploratory descriptive correlational design was utilized to achieve the objectives of the current study.

\section{Sampling and setting}

A convenient sampling technique was used to collect data from undergraduate nursing students studying at nursing colleges affiliated to king Saud Bin Abdul-Aziz University for Health Sciences, Jeddah.

To achieve the purpose of the present study 3 main tools were used, it consisted of:

- First part: Socio-demographic characteristics sheet of the participants contains questions enquires about; age, academic year, academic performance (GPA), marital states, stream, residence, number of hours spent on the Internet.

- Second instrument: The Arabic version of Internet Addiction Test (IAT) was administrated to assess the prevalence rate of IA among nursing students. Originally, IAT was designed by Young (1995). The Arabic version of IAT has been validated in a study conducted in Lebanon by Hawi (2013). It is a self-rated test that contains 20 items.Each item was scored on a scale of 0-5. As 0 means (Does not apply) to 5 (Always). A three categorical score was given to describe the level of Internet addiction as following: a score of 20-49 suggests controlled or average usage (mild addiction), a score of 50-79 suggests occasional or frequent problems (moderate addiction); and a score of 80-100 suggests significant problems (severe addiction). IA was assessed by summing the scores and scores $\geq 50$ were classified as IA (Young 1995). IAT is the most popular and commonly used instrument for the measurement of Internet addiction. The tool validity and reliability were confirmed through a reported study that indicated adequate reliability of Chinese, Arabic and English (Cronbach alpha $\geq$ 0.90) (Guan et al. 2012, Khazaal et al. 2008). 
- Third instrument: Center for Epidemiologic Studies Depression Scale (CES-D) developed by (Radloff 1977) which has been used extensively in studies of adolescents. The respondents were asked to complete the 20-item of the Depression Scale by indicating how often they have felt or behaved during the past week. All Items are rated from 0 to 3, except for items no. $4,8,12$, \& 16 were rated in reverse as rated from 3 to 0 . The Score is the sum of the 20 item weights. A score of 16 or greater is considered depressed. The (CES-D) scale had a very Internal Consistency Reliability (Cronbach alpha $=\geq 0.91)$.

\section{Data management and analysis plan}

The data was analyzed by using the most recent SPSS version 20. The collected data was coded; validated, cleaned and the missing data was controlled before the analysis. Appropriate statistical tests such as, descriptive statistics (frequencies, percentages, and graphs) and the association among variables of the study with socio-demographic background by using the Spearman Rank Order Correlations. A suitable test will be used to achieve the current study objectives.

\section{Ethical and legal consideration}

An official permission from the College Ethical Research Committee in the nursing college was taken for data collection. The participants learned about the nature and the objective of the study, that their participation is voluntary and that they can revoke from the study at any time. A written consent was obtained from all participants. The confidentiality and anonymity of the collected data was assured for all participants.

\section{Results}

Table 1 shows the demographic criteria of studied participants. Their age ranged between $18-30$ with $21.17 \pm 3.9$, while their GPA ranged from 1.75 to 4.6 with a total mean of $3.63 \pm 0.59$.

Table 1. Socio-Demographic Characteristics of the Study Nurses

\begin{tabular}{|l|c|c|c|c|}
\hline & Minimum & Maximum & Mean & $\mathbf{\pm S D}$ \\
\hline Age (years) & 18 & 30 & 21.17 & 3.88 \\
\hline GPA & 1.75 & 4.6 & 3.63 & 0.59 \\
\hline
\end{tabular}

Source: Authors' calculations.

Table 2 shows that the majority $(77.5 \%)$ of participants were in stream I, 91.2\% were single and $82.9 \%$ lived in Jeddah. 
Table 2. Frequency Distribution of Participants' Demographic Characteristics

\begin{tabular}{|c|c|c|}
\hline Variables & No & $\%$ \\
\hline $\begin{array}{c}\text { Educational Program } \\
\text { Stream I } \\
\text { Stream II }\end{array}$ & $\begin{array}{c}110 \\
37\end{array}$ & $\begin{array}{l}77.5 \% \\
25.2 \%\end{array}$ \\
\hline $\begin{array}{c}\text { Marital Status } \\
\text { Single } \\
\text { Married } \\
\end{array}$ & $\begin{array}{c}134 \\
13 \\
\end{array}$ & $\begin{array}{l}91.2 \% \\
52.8 \% \\
\end{array}$ \\
\hline $\begin{array}{l}\text { Jeddah } \\
\text { Makkah } \\
\text { Madinah }\end{array}$ & $\begin{array}{c}122 \\
23 \\
2\end{array}$ & $\begin{array}{l}82.9 \% \\
15.6 \% \\
1.5 \%\end{array}$ \\
\hline
\end{tabular}

Source: Authors' calculations.

Graph 1 shows the time spent by studied participants on the Internet, nearly half $42.5 \%$ of them spent 5-7 hours followed by $24.0 \%$ spent $2-4$ hours and only $19.2 \%$ spent 10 hours or more.

Graph 1. Time Spent in the Internet

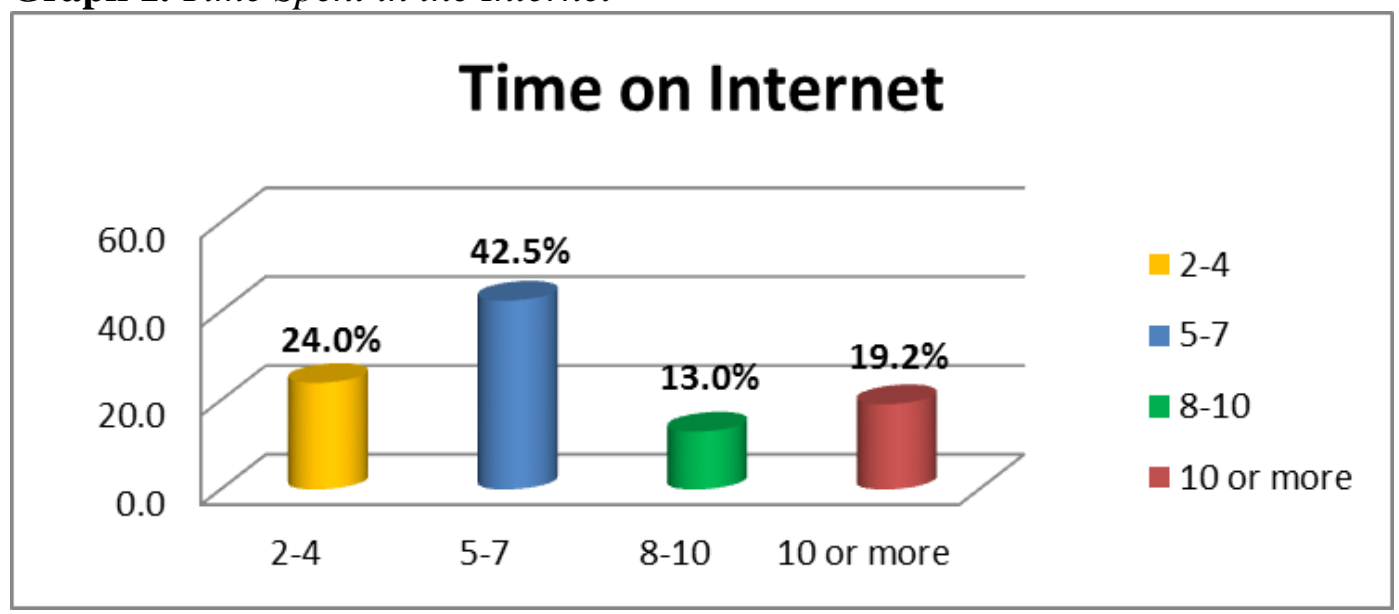

Source: Authors' calculations.

Table 3 shows the frequency of distribution for Internet addiction statements among the studied participants. Most of the participants scores ranged from rarely and frequently using Internet except for item no. 1, 2, 5, 11, and $12(6.8 \%, 13.0 \%, 13.1 \%, 20.0 \%$ and $9.6 \%)$ respectively. 
Table 3. Frequency Distribution for Internet Addiction Statements

\begin{tabular}{|c|c|c|c|c|c|c|c|c|c|c|}
\hline \multirow[t]{2}{*}{ Statements } & \multicolumn{2}{|c|}{ Rarely } & \multicolumn{2}{|c|}{ Occasion } & \multicolumn{2}{|c|}{ Frequent. } & \multicolumn{2}{|c|}{ Often } & \multicolumn{2}{|c|}{ Always } \\
\hline & $\mathbf{N}$ & $\%$ & $\mathbf{N}$ & $\%$ & $\mathbf{N}$ & $\%$ & $\mathbf{N}$ & $\%$ & $\mathbf{N}$ & $\%$ \\
\hline $\begin{array}{l}\text { 1. How often do you find that you } \\
\text { stay on-line longer than you } \\
\text { intended? }\end{array}$ & 10 & 6.8 & 36 & 24.7 & 52 & 35.6 & 25 & 17.1 & 23 & 15.8 \\
\hline $\begin{array}{l}\text { 2. How often do you neglect } \\
\text { household chores to spend more } \\
\text { time on-line? }\end{array}$ & 19 & 13.0 & 48 & 32.9 & 49 & 33.6 & 21 & 14,4 & 9 & 6.2 \\
\hline $\begin{array}{l}\text { 3. How often do you prefer the } \\
\text { excitement of the Internet to } \\
\text { intimacy with your partner? }\end{array}$ & 59 & 44.4 & 38 & 28.6 & 23 & 17.3 & 8 & 6.0 & 5 & 3.8 \\
\hline $\begin{array}{l}\text { 4. How often do you form new } \\
\text { relationships with fellow on- } \\
\text { line users? }\end{array}$ & 44 & 30.3 & 48 & 33.1 & 32 & 22.1 & 14 & 9.7 & 7 & 4.8 \\
\hline $\begin{array}{l}\text { 5. How often do others in your life } \\
\text { complain to you about the } \\
\text { amount of time you spend on- } \\
\text { line? }\end{array}$ & 19 & 13.1 & 60 & 41.4 & 33 & 22.8 & 19 & 13.1 & 14 & 9.7 \\
\hline $\begin{array}{l}\text { 6. How often do your grades or } \\
\text { school work suffers because of } \\
\text { the amount of time you spend } \\
\text { on-line? }\end{array}$ & 42 & 29.8 & 46 & 32.6 & 43 & 30.5 & 8 & 5.7 & 2 & 1.4 \\
\hline $\begin{array}{l}\text { 7. How often do you check your } \\
\text { email before something else } \\
\text { that you need to do? }\end{array}$ & 40 & 27.4 & 54 & 37.0 & 29 & 19.9 & 9 & 6.2 & 14 & 0.6 \\
\hline $\begin{array}{l}\text { 8. How often does your job } \\
\text { performance or productivity } \\
\text { suffer because of the Internet? }\end{array}$ & 46 & 32.6 & 51 & 36.2 & 32 & 22.7 & 7 & 5.0 & 5 & 3.5 \\
\hline $\begin{array}{l}\text { 9. How often do you become } \\
\text { defensive or secretive when } \\
\text { anyone asks you what you do } \\
\text { on-line? }\end{array}$ & 50 & 34.2 & 47 & 32.2 & 23 & 15.8 & 16 & 11.0 & 10 & 6.8 \\
\hline $\begin{array}{l}\text { 10. How often do you block out } \\
\text { disturbing thoughts about your } \\
\text { life with soothing thoughts of } \\
\text { the Internet? }\end{array}$ & 34 & 23.4 & 39 & 26.9 & 41 & 28.3 & 18 & 12.4 & 13 & 9.0 \\
\hline $\begin{array}{l}\text { 11. How often do you find yourself } \\
\text { anticipating when you will go } \\
\text { on-line again? }\end{array}$ & 29 & 20.0 & 40 & 27.6 & 42 & 29.0 & 13 & 9.0 & 21 & 14.5 \\
\hline $\begin{array}{l}\text { 12. How often do you fear that life } \\
\text { without the Internet would be } \\
\text { boring, empty, and joyless? }\end{array}$ & 14 & 9.6 & 31 & 21.2 & 41 & 28.1 & 17 & 11.6 & 43 & 29.5 \\
\hline $\begin{array}{l}\text { 13. How often do you snap, yell, or } \\
\text { act annoyed if someone bothers } \\
\text { you while you are on-line? }\end{array}$ & 39 & 26.7 & 50 & 34.2 & 32 & 21.9 & 19 & 13.0 & 6 & 4.1 \\
\hline $\begin{array}{l}\text { 14. How often do you lose sleep } \\
\text { due to late-night log-ins? }\end{array}$ & 37 & 25.7 & 34 & 23.6 & 38 & 26.4 & 14 & 9.7 & 21 & 14.6 \\
\hline $\begin{array}{l}\text { 15. How often do you feel } \\
\text { preoccupied with the Internet } \\
\text { when off-line, or fantasize } \\
\text { about being on-line? }\end{array}$ & 58 & 39.7 & 29 & 19.9 & 33 & 22.6 & 15 & 10.3 & 11 & 7.5 \\
\hline
\end{tabular}




\begin{tabular}{|c|c|c|c|c|c|c|c|c|c|c|}
\hline $\begin{array}{c}\text { 16. How often do you find yourself } \\
\text { saying "just a few more } \\
\text { minutes" when on-line? }\end{array}$ & 46 & 31.5 & 39 & 26.7 & 34 & 23.3 & 14 & 9.6 & 13 & 8.9 \\
\hline $\begin{array}{c}\text { 17. How often do you try to cut } \\
\text { down the amount of time you } \\
\text { spend on-line and fail? }\end{array}$ & 37 & 25.5 & 46 & 31.7 & 38 & 26.2 & 11 & 7.6 & 13 & 9.0 \\
\hline $\begin{array}{c}\text { 18. How often do you try to hide how } \\
\text { long you have been on-line? }\end{array}$ & 74 & 51.7 & 26 & 18.2 & 24 & 16.8 & 14 & 9.8 & 5 & 3.5 \\
\hline $\begin{array}{c}\text { 19. How often do you choose to } \\
\text { spend more time on-line over } \\
\text { going out with others? }\end{array}$ & 45 & 30.8 & 54 & 37.0 & 33 & 22.6 & 8 & 5.5 & 6 & 4.1 \\
\hline $\begin{array}{c}\text { 20. How often do you feel } \\
\text { depressed, moody or nervous } \\
\text { when you are off-line, which } \\
\text { goes away once you are back } \\
\text { on-line? }\end{array}$ & 43 & 29.5 & 52 & 35.6 & 28 & 19.2 & 15 & 10.3 & 8 & 5.5 \\
\hline
\end{tabular}

Source: Authors' calculations.

Table 4. Frequency Distribution for Depression Statements

\begin{tabular}{|c|c|c|c|c|c|c|c|c|}
\hline \multirow[t]{3}{*}{ Statements } & \multicolumn{8}{|c|}{ During the past week } \\
\hline & \multicolumn{2}{|c|}{$\begin{array}{l}\text { Rarely } \\
\text { (less } \\
\text { than } 1 \\
\text { day) }\end{array}$} & \multicolumn{2}{|c|}{$\begin{array}{l}\text { Some of } \\
\text { the time } \\
\text { (1-2 days) }\end{array}$} & \multicolumn{2}{|c|}{$\begin{array}{l}\text { Occasionally } \\
(3-4 \text { days })\end{array}$} & \multicolumn{2}{|c|}{$\begin{array}{l}\text { Most of the } \\
\text { time (5-7 } \\
\text { days) }\end{array}$} \\
\hline & $\mathbf{N}$ & $\%$ & $\mathbf{N}$ & $\%$ & $\mathbf{N}$ & $\%$ & $\mathbf{N}$ & $\%$ \\
\hline $\begin{array}{l}\text { 1. I was bothered by things that } \\
\text { usually do not bother me. }\end{array}$ & 65 & 44.8 & 45 & 31.0 & 23 & 15.9 & 12 & 8.3 \\
\hline $\begin{array}{l}\text { 2. I did not feel like eating; my } \\
\text { appetite was poor. }\end{array}$ & 59 & 40.7 & 64 & 44.1 & 18 & 12.4 & 4 & 2.8 \\
\hline $\begin{array}{l}\text { 3. I felt that I could not shake off the } \\
\text { blues even with help from my } \\
\text { family or friends. }\end{array}$ & 51 & 36.2 & 62 & 44.0 & 21 & 14.9 & 7 & 5.0 \\
\hline 4. I felt I was just as good as other people. & 36 & 25.7 & 52 & 37.1 & 39 & 27.9 & 13 & 9.3 \\
\hline $\begin{array}{l}\text { 5. I had trouble keeping my mind on } \\
\text { what I was doing. }\end{array}$ & 39 & 27.9 & 58 & 41.4 & 34 & 24.3 & 9 & 6.4 \\
\hline 6. I felt depressed. & 56 & 38.1 & 52 & 35.4 & 33 & 22.4 & 6 & 4.1 \\
\hline $\begin{array}{l}\text { 7. I felt that everything I did was an } \\
\text { effort. }\end{array}$ & 38 & 26.2 & 58 & 40.0 & 35 & 24.1 & 14 & 9.7 \\
\hline 8. I felt hopeful about the future. & 30 & 20.8 & 37 & 25.7 & 32 & 22.2 & 45 & 31.3 \\
\hline 9. I thought my life had been a failure. & 70 & 49.0 & 40 & 28.0 & 24 & 16.8 & 9 & 6.3 \\
\hline 10. I felt fearful. & 59 & 40.7 & 54 & 37.2 & 23 & 15.9 & 9 & 6.2 \\
\hline 11. My sleep was restless. & 39 & 27.7 & 51 & 36.2 & 32 & 22.7 & 19 & 13.5 \\
\hline 12. I was happy. & 26 & 17.8 & 45 & 30.8 & 38 & 26.0 & 37 & 25.3 \\
\hline 13. I talked less than usual. & 42 & 30.2 & 53 & 38.1 & 30 & 21.6 & 14 & 10.1 \\
\hline 14. I felt lonely. & 69 & 47.9 & 42 & 29.2 & 27 & 18.8 & 6 & 4.2 \\
\hline 15. People were unfriendly. & 54 & 37.0 & 54 & 37.0 & 28 & 19.2 & 10 & 6.8 \\
\hline 16. I enjoyed life. & 33 & 23.1 & 36 & 25.2 & 31 & 21.7 & 43 & 30.1 \\
\hline 17. I had crying spells. & 62 & 43.1 & 51 & 35.4 & 25 & 17.4 & 6 & 4.2 \\
\hline 18. I felt sad. & 59 & 41.0 & 55 & 38.2 & 21 & 14.6 & 9 & 6.3 \\
\hline 19. I felt that people dislike me. & 74 & 52.1 & 42 & 30.3 & 20 & 14.1 & 5 & 3.5 \\
\hline 20. I could not get "going". & 58 & 39.7 & 57 & 39.0 & 26 & 17.8 & 5 & 3.4 \\
\hline
\end{tabular}

Source: Authors' calculations. 
Table 4 shows the frequency of distribution for statements among studied participants. Most of the participants scores ranged from rarely and some of the day and occasionally felt depressive symptoms except for statements no. 4 $(25.7 \%)$, no. $5(27.9 \%)$, and no. 7 (26.2\%), respectively.

Table 5 showed the total mean of the depression score was $20.18 \pm 7.743$ while $48.53 \pm 13.851$ was given for IA total score.

Table 5. Mean and Standard Division for Depression and Internet Addiction

\begin{tabular}{|l|c|c|c|c|c|}
\hline & $\mathbf{N}$ & Minimum & Maximum & Mean & Std. Deviation \\
\hline Depression total score & 147 & 3 & 51 & 20.18 & 7.743 \\
\hline Addiction total score & 147 & 27 & 88 & 48.53 & 13.851 \\
\hline
\end{tabular}

Source: Authors' calculations.

Pie chart 1 shows classification of students according to Internet addiction categories of score and depression. The total score for IA was categorized into 3 mains categories accordingly almost two third (59.6\%) of the participant students were in average online use followed by $38.4 \%$ occasionally or frequently used and only $2.1 \%$ were faced with significant problem so they are significantly used the online intranet. Pie chart 2 shows the prevalence of depression among student participants, it is surprising that more than 2 third $(64.6 \%)$ of them suffering from depression compared by $35.4 \%$ had no depressive symptoms.
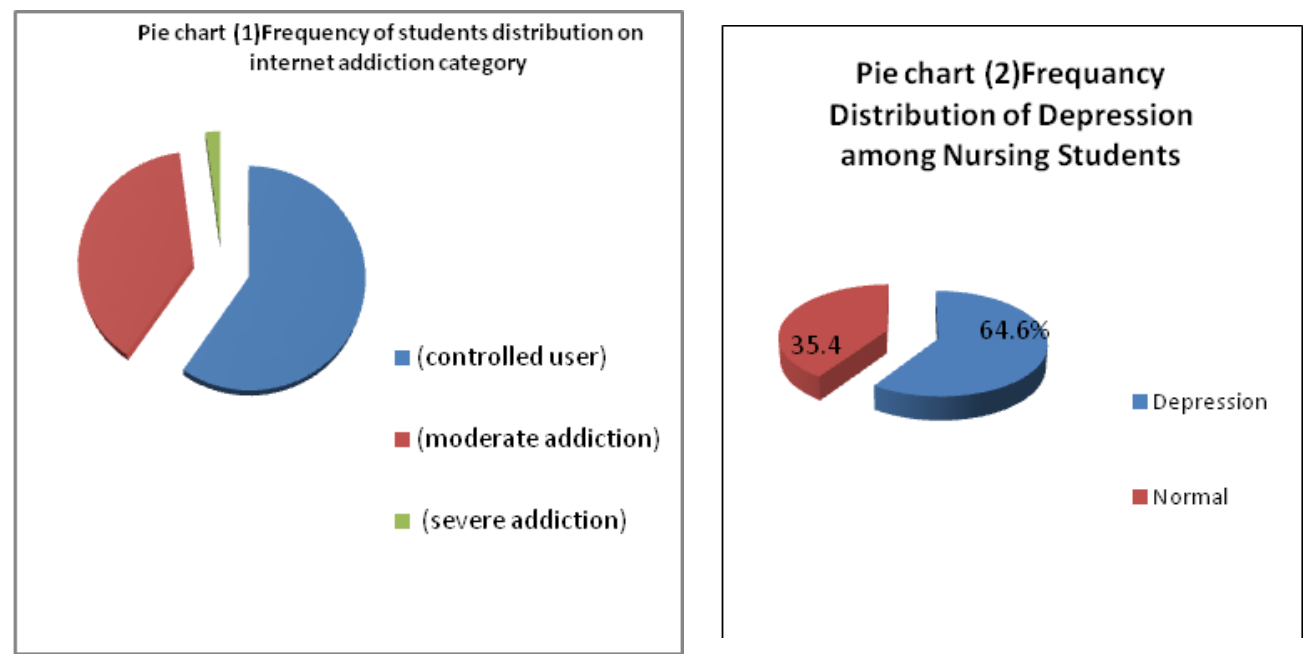

Source: Authors' calculations.

Regarding the correlation between age, GPA, time on Internet, addiction and depression, the results showed that there is a significant correlation between Internet addiction $(r=0.335)$ and the time spent on line and depressive morbidity $(\mathrm{r}=0.205)$ and IA, while age of participants and GPA did not show any significant correlation with any of the measured variables of IA and the depression scale (Table 7). 
Table 7. Pearson Correlation between Age, GPA, Time on Internet, Addiction and Depression

\begin{tabular}{|l|c|c|c|c|c|}
\hline & Age & GPA & Time on Internet & Addiction & Depression \\
\hline Age & 1 & & & & \\
\hline GPA & -0.055 & 1 & & & \\
\hline $\begin{array}{l}\text { Time on } \\
\text { Internet }\end{array}$ & 0.002 & -0.112 & 1 & & \\
\hline Addiction & -0.003 & -0.128 & $0.335^{* *}$ & 1 & \\
\hline Depression & -0.061 & 0.150 & 0.057 & $0.205^{*}$ & 1 \\
\hline
\end{tabular}

Source: Authors' calculations.

** Correlation is significant at the 0.01 level (2-tailed).

* Correlation is significant at the 0.05 level (2-tailed).

\section{Discussion}

Internet addiction (IA) is a comparatively recent arena of academic and educational inquiry. Experiential researches proposed that IA, like other well researched addictive behaviors, has an influence on many features of individuals' daily living activities, such as academic work performance, socialization, and physical and psychological health (Goldberg 1996, Young 1996).

The main objective of the current study was to examine the prevalence of IA among nursing students and its association with their academic performance and mental health in king Saud Bin Abdul-Aziz University for health sciences, Jeddah.

The current research finding revealed that $38.4 \%$ and $2.1 \%$ of our participants were categorized as moderate to severe Internet addiction respectively. This result is congruent with Alhajjar (2014) in his study in a Palestine sample of students at Gaza strip as he found that $30.1 \%$ were at risk for Internet addiction. Also, Lam et al. (2014) in their study found that $10.2 \%$ of the studied adolescents were moderately addicted, and $0.6 \%$ were severely addicted to the Internet.

Moreover, there have been several studies about the prevalence rate of Internet addiction in the middle and Far East. Among those studies an Iranian study done by Mazhari (2012) examining the prevalence of IA among medical students as she found that $21 \%$ of the students were identified as problematic Internet users, and Kheirkhah et al. (2010) investigated the prevalence of Internet addiction in the Mazandaran province as they found that $22.8 \%$ of the Internet users were Internet addicts and Internet addiction was significantly higher in males and younger age groups. In fact an extensive body of research concluded that $54.7 \%$ of Internet addicts were university students (Kheirkhah et al. 2010).

Besides, university students are among high risk groups for Internet addiction because they use the Internet for both educational purposes, such as doing assignments and searching information sources and non-educational purposes like communication with friends and entertainment. In addition, easy 
access to the Internet in the universities and absence of parental control are factors resulting in Internet overuse by university students. Accordingly, the previous research done in European university students reported the higher prevalence rate of Internet addiction among them as it has been reported to be $4 \%$ in the United States, $10.6 \%$ in China, $5.9 \%$ and $17.9 \%$ in Taiwan, and $34.7 \%$ in Greece (Chou and Hsiao 2000, Wu and Zhu 2004, Christakis et al. 2011, Frangos and Sotiropoulos 2011).

Regarding the prevalence of depression among the studied sample, the present research finding is very surprising as more than 2 thirds $(64.6 \%)$ of participants had depression and has a significant correlation with Internet addiction. This reported results goes on the same track with the results of previous research and perspectives conducted by Li and Chung (2006) Mesch (2001), Treuer et al. (2001) and Yellowlees and Marks (2005) who noted that students who were categorized as pathological and excessive user of the Internet, their mental health would be declined. They found that the students who use Internet pathologically and excessively, showed greater psychiatric vulnerability for depression and suicidal ideation and psychological problems such as anxiety and self-injurious behavior than students who did not have such experiences. Indeed, the current research results are in the same line with findings of Iqbal et al. (2014), Kutty and Sreeramareddy (2014), Muussesa et al. (2014), Yoo et al. (2013), Bidi et al. (2012), Alavi et al. (2010), Kim et al. (2006), and Alhajjar (2014).

As mentioned earlier that, college students experienced a lot of stressors throughout their life. Among those stressors that may involve different types of life events such as interpersonal problems, school related problems, family related problems and personal problems that characterized by either higher or lower frequency of occurrence. Accordingly, Jie et al. (2014) found in his study that life stress from inter personal and school correlated positively with IA. Moreover, nursing students face a lot of stress factors in their educational experiences such as clinical settings environment, death and dying patients, barrier in application of their clinical skills, conflict relationship with nurses and patients, examinations ,curriculum and academic workload and lack of free recreational time (Gibbons et al. 2009, Pryjmachuk and Richards 2008).

Several studies proved that Internet addiction has a negative impact on the academic performance of the students (Akhter 2013, Asemah et al. 2013, Sachitra 2015, and Wang et al. 2011). Those results are not consistence with our findings as no association was found between IA and students' academic performance. This may be due to limited response rate from the participants since the study sample was recruited conveniently from female students applied to one program (nursing program) in the university and the research relies on self-report and voluntary response, and the comparison between two genders has a major role in the findings of previous studies on IA. Also, it was reported that female students usually have a higher GPA than male students.

In a previous study done by Nasiri et al. (2011) they reported that students try to forget the stress of academic work load by spending more time in intranet this is in the same line with our finding of significant correlation was found 
between time spent in intranet and IA. The evidence of IA has been recommended by an extensive body of research as it was reported that some of the Internet users spend longer periods of time connected and experience alienation, isolation and depressive symptoms when offline. Besides, the preoccupied individuals with electronic games, search and recreational activities may be liable to neglect sporting and aerobic exercise, and familial communication as well as societal accomplishments (Kim et al. 2010, Nalwa and Anand 2003, Seo et al. 2009, Yang and Tung 2007, Young 2004).

\section{Conclusion and Recommendations}

From the current study findings it was concluded that nursing students are experienced moderate to severe levels of Internet addiction without any impact on their academic performance with higher prevalence rate of psychiatric and psychological morbidity for depression.

Therefore, it is urgent and important to pay more attention to medical and nursing colleges students' psychological morbidity for IA and depression. Conducting an in-services educational program, for college students, that provides information about the impact of the pathological use of online use on their physical, psychological and mental health. In addition, providing controlled intranet services in the university compound may play an important role in decreasing the prevalence of IA among students. It is recommended to replicating the study using both genders and studying the reasons for Internet addiction and depression as it may be rooted in some common etiological factors that requires further exploration. Also, future studies on the relationship between Internet addiction and stressful life events may provide a clear explanation for the higher prevalence rate of depression among college students.

\section{References}

Akhter N (2013) Relationship between Internet Addiction and Academic Performance among University Undergraduates. Educational Research and Review 8(19): 1793-1796.

Alavi S, Maracy M, Jannatifard F, Eslami M, Haghighi M (2010). A Survey of Relationship between psychiatric symptoms and Internet addiction in students of Isfahan universities. Scientific Journal of Hamadan University of Medical Sciences and Health Services 17(2): 57-65.

Alhajjar B (2014) Internet addiction and psychological morbidity among nursing students in Gaza-Palestine. American Journal of Applied Psychology 3(4): 99103.

Asemah ES, Okpanachi RA, Edegoh LON (2013) Influence of Social Media on the Academic Performance of the Undergraduate Students of Kogi State University, Anyigba, Nigeria. Research on Humanities and Social Sciences 3(12): 90-96. 
Bidi F, Namdari-Pejman M, Kareshki H, Ahmadnia H (2012) The Mediating role of metacognition in the relationship between Internet addiction and general health. Addiction \& Health 4(1-2): 49-56.

Chou C, Hsiao MC (2000) Internet addiction, usage, gratification, and pleasure experience: the Taiwancollege students' case. Computers and Education 35(1): 65-80.

Christakis D, Moreno M, Jelenchick L, Myaing M, Zhou C (2011) Problematic Internet usage in US college students: a pilot study. BioMed Central Medicine 9: 77. DOI: $10.1186 / 1741-7015-9-77$.

De Rick A, Vanheule S (2007) Attachment styles in alcoholic inpatients. European Addiction Research 13: 101-108.

Frangos CC, Sotiropoulos I (2011) Problematic Internet Use among Greek university students: Ordinal logistic regression with risk factors of negative psychological beliefs, pornographic sites, and online games. Cyberpsychology, Behavior, and Social Networking 14(1-2): 51-58.

Fu KW, Chan WS, Wong PW, Yip PS (2010) Internet addiction: prevalence, discriminant validity and correlates among adolescents in Hong Kong. The British Journal of Psychiatry 196: 486-492.

Gibbons C, Dempster M, Moutray M (2009) Surveying nursing students on their sources of stress: A validation study. Nurse Education Today 29(8): 867-872.

Goldberg I (1996) Internet addictive disorder (IAD) diagnostic criteria. [Online] Retrieved from: http://goo.gl/8WHkuM. [Accessed: 27 July 2007]

Guan NC, Isa SM, Hashim AH, Pillai SK, Singh MKH (2012) Validity of the Malay version of the Internet addiction test: A study on a group of medical students in Malaysia. Asia-Pacific Journal of Public Health 27(2).

Hosseini M, Ashktorab T, Taghdisi MH, Esmaeili SA, Rafiei H (2015) Healthpromoting behaviors and their association with certain demographic characteristics of nursing students of Tehran city in 2013. Global Journal of Health Science 7(2): 264-272.

Hawi N (2013) Arabic validation of the Internet Addiction Test. Cyberpsychology, Behavior, and Social Networking 16(3): 200-204.

Holden C (2001) "Behavioural" addictions: do they exist? Science 294: 980-982.

Iqbal M, Noor M, Miann A (2014) Analysis of Internet addiction amongst university level students. VFAST Transactions on Software Engineering 3(2): 11-16.

Jahanian R, Seifury Z (2013) The Impact of Internet Addiction on Students' Mental Health in Technical and Vocational Colleges in Alborz Province. Middle-East Journal of Scientific Research 14(11): 1533-1538.

Jenaro C, Flores N, Gómez-Vela M, González-Gil F, Caballo C (2007) Problematic Internet and cell-phone use: Psychological, behavioral, and health correlates. Addiction Research \& Theory 15: 309-320.

Jie T, Yizhen Y, Yukai D, Yingc M, Dongying Z, Jiaji W (2014) Prevalence of Internet addiction and its association with stressful life events and psychological symptoms among adolescent Internet users. Addictive Behaviors 39: 744-747.

Jung Koo H, Hye Kwon J (2014) Risk and protective factors of Internet addiction: A meta-analysis of empirical studies in Korea. Yonsei Medical Journal 55(6).

Kapahi A, Ling CS, Ramadass S, Abdullah N (2013) Internet Addiction in Malaysia Causes and Effects. iBusiness 5: 72-76.

Khazaal Y, Billieux J, Thorens G, Khan R, Louati Y, Scarlatti E, et al. (2008) French validation of the Internet addiction test. Cyberpsychology, Behavior, and Social Networking 11: 703-706. 
Kheirkhah F, GhabeliJuibary A, Gouran A (2010) Internet Addiction, Prevalence and Epidemiological Features in Mazandaran Province, Northern Iran. The Iranian Red Crescent Medical Journal 12(2): 133-137.

Kim K, Ryu E, Chon M, Yeun E, Choi S, Seo J, et al. (2006) Internet addiction in Korean adolescents and its relation to depression and suicidal ideation: a questionnaire survey. International Journal of Nursing Studies 43(2): 185-192.

Kim JH, Hui HLC, Lau CH, Kan P, Cheuk KK, Griffiths M (2010) Brief report: Predictors of heavy Internet use and associations with health promoting and health risk behaviors among Hong Kong university students. Journal of Adolescence 33(1): 215-220.

Ko C-H, Yen J-Y, Yen C-F, Lin H-C, Yang M-J (2007) Factors predictive for incidence and remission of Internet addiction in young adolescents: A prospective study. Cyber Psychology \& Behavior 10: 545-551.

Ko C-H, Yen J-Y, Yen C-F, Chen C-S, Chen C-C (2012). The association between Internet addiction and psychiatric disorder: A review of the literature. European Psychiatry 27: 1-8.

Kutty N, Sreeramareddy C (2014) A cross-sectional online survey of compulsive Internet use and mental health of young adults in Malaysia. Journal of Family and Community Medicine 21(1): 23-28.

Kheirkhah F, Ghabeli Juibary A, Gouran A (2010) Internet Addiction, Prevalence and Epidemiological Features in Mazandaran Province, Northern Iran. The Iranian Red Crescent Medical Journal 12(2): 133-137.

Lam LT, Peng M. Jing J (2014) The association between Internet addiction and self injurious behavior among adolescents. Injury Prevention 15(6): 403-408.

Li D, Zhang W, Li X, Zhen S, Wang Y (2010). Stressful life events an problematic Internet use by adolescent females and males: A mediated moderation model. Computers in Human Behavior 26: 1199-1207.

Li S, Chung T (2006) Internet function and Internet addictive behavior. Computers in Human Behavior 22: 1067-1071.

Lin F, Zhou Y, Du Y, Zhao Z, Qin L, Xu J, Lei H (2015) Aberrant corticostriatal functional circuits in adolescents with Internet addiction disorder. Frontiers in Human Neuroscience 16(9): 356. DOI: 10.3389/fnhum.2015.00356.

McNally AM, Palfai TP, Levine RV, Moore BM (2003) Attachment dimensions and drinking-related problems among young adults: the meditational role of coping motives. Addictive Behaviors 28: 1115-1127.

Mesch G (2001) Social relationship and Internet use among adolescents in Israel. Social Science Quarterly 82(2): 329-339.

Miniwatts Marketing Group (2010) World Internet Users and Population Statistics. Retrieved from: http://goo.gl/L8hG. [Accessed: 3 February 2010]

Mohammadsalehi N, Mohammadbeigi A, Jadidi R, Anbari Z, Ghaderi E, Akbari M (2015) Psychometric properties of the persian language version of yang internet addiction questionnaire: an explanatory factor analysis. International Journal of High Risk Behaviors and Addiction 4(3).

Mazhari S (2012) The prevalence of problematic internet use and the related factors in medical students, Kerman, Iran. Addiction and Health 4(3-4): 87-94.

Muussesa L, Finkenauerb C, Kerkhofc P, Billedoc C (2014). A longitudinal study of the association between Compulsive Internet use and wellbeing. Computers in Human Behavior 36: 21-28.

Nalwa K, Anand AP (2003) Internet Addiction in Students: A Cause of Concern. Cyberpsychology and Behavior 6(6): 653-656. 
Nasiri E, Raei M, Vatani J, Keshavarz S, Hashiani A (2011) Survey the prevalence of internet addiction and its influential factors in Persian college student in 2011. Middle-East Journal of Scientific Research 10(1): 50-53.

Neumann PG (1998) Are Computers Addictive? Communications of the ACM 41: 128-129.

Pryjmachuk S, Richards D (2008) Predicting stress inpre-registration midwifery students attending a university in Northern England. Midwifery 24(1): 108-122.

Pirzadeh A (2012) The relation between general health and Internet addiction in medical students, Isfahan, Iran. Journal of Health System Research 8(1): 52-58. [In Persian]

Radloff LS (1977) The CES-D scale - A self-report depression scale for research in the general population. Applied Psychological Measurement 1: 385-401.

Seo M, Kang HS, Yom YH (2009) Internet addiction and interpersonal problems in Korean adolescents. Cin-Computers Informatics Nursing 27(4): 226-233.

Shahrzad Mazhari MD (2012) The prevalence of problematic internet use and the related factors in medical students, Kerman, Iran. Addiction of Health 4(3-4): 8794.

Shapira NA, Lessig MC, Goldsmith TD, Szabo ST, Lazoritz M, Gold MS, Stein DJ (2003) Problematic Internet use: proposed classification and diagnostic criteria. Depress Anxiety 17(4): 207-216.

Shaw M, Black DW (2007) Internet addiction: definition, assessment, epidemiology and clinical management. CNS Drugs 22: 353-365.

Shin SE, Kim NS, Jang EY (2-011) Comparison of problematic Internet and alcohol use and attachment styles among industrial workers in Korea. Cyberpsychology, Behavior, and Social Networking 14: 665-672.

Sung J, Lee J, Noh H-M, Park YS, Ahn EJ (2013) Associations between the risk of Internet addiction and problem behaviors among Korean adolescents. Korean Journal of Family Medicine 34: 115-122.

Treuer T, Fabian Z, Furedi J (2001) Internet addiction associated with features of impulse control disorder: is it a real psychiatric disorder? Journal of Affective Disorders 66(2-3): 283.

Velezmoro R, Lacefield K, Roberti JW (2010) Perceived stress, sensation seeking, and college students' abuse of the Internet. Computers in Human Behavior 26(6): 1526-1530.

Sachitra V (2015) Relationship between Internet Addiction and Academic Performance among University Undergraduates. Retrieved from: http://goo.gl/3ayNF1.

Wang H, Zhou X, Lu C, Wu J, Deng X, Hong L (2011) Problematic Internet use in high school students in Guangdong province, China. PLoS One 6(5).

$\mathrm{Wu} \mathrm{HR}$, Zhu KJ (2004) Path analysis on related factors causing. Internet addiction disorder in college students. Chinese Journal of Public Health 20: 1363-1364.

Yan W, Li Y, Sui N (2013) The relationship between recent stressful life events, personality traits, perceived family functioning and Internet addiction among college students. Stress and Health 30(1): 3-11.

Yang S, Tung C (2007) Comparison of Internet addicts and non-addicts in Taiwanese high school. Computers in Human Behavior 23(1): 79-96.

Yellowlees P, Marks S (2005) Problematic Internet use or Internet addiction? Computers in Human Behavior 23(3): 1447-1453.

Yen J-Y, Ko C-H, Yen C-F, Chen S-H, Chung W-L, Chen C-C (2008) Psychiatric symptoms in adolescents with Internet addiction: comparison with substance use. Psychiatry and Clinical Neurosciences 62: 9-16. 
Yoo Y, Cho O, Cha K (2014) Associations between overuse of the Internet and mental health in adolescents. Nursing \& Health Sciences 16(2): 193-200.

Young K (2004) Internet Addiction: A new clinical phenomenon and its consequences. American Behavioral Scientist 48(4): 402-415.

Young KS, Rogers RC (1998) The relationship between Depression and Internet Addiction. Cyber Psychology Behaviour 1: 25-2

Young KS (1995) Internet addiction test. Retrieved from: http://netaddiction.com/.

Young KS (1996) Internet addiction: The emergence of a new clinical disorder. Poster presented at the 104th American Psychological Association Annual Convention, Toronto, Canada.

Zhang Y, Mei S, Li L, Chan J, Li J, Du H (2015) The relationship between impulsivity and Internet addiction in Chinese college students: A moderated mediation analysis of meaning in life and self-esteem. Plos One 10(7): 1-13. 